\title{
COMPARATIVE ESTIMATE OF RESISTANCE TO DROUGHT FOR SELECTED KARSTIC AQUIFERS IN BULGARIA
}

\author{
Tatiana Orehova
}

\begin{abstract}
Effective management of water resources requires adequate knowledge of groundwater system including the influence of climate variability and climate change. The drought of 1982-1994 in Bulgaria has led to important decrease of springflow and lowering of water levels. Therefore, groundwater demonstrated its vulnerability to drought. The purpose of this paper is to determine relative resistance of selected aquifers in Bulgaria to a prolonged decrease of recharge to groundwater. The drought resistance indicator has been defined for some karstic aquifers based on the method proposed in report of BRGM. The data from National Hydrogeological Network located in the National Institute of Meteorology and Hydrology were processed. For the aim of this study, time-series of discharge for karstic springs were used. Stations with significant impact of human activity on groundwater were eliminated. The results show that most of studied aquifers in Bulgaria have moderate and weak resistance to the drought. They are vulnerable to droughts and need good management for effective use of groundwater resources.
\end{abstract}

Keywords: karst, aquifer, drought, resistance.

\section{Introduction}

Effective management of water resources requires adequate knowledge of the groundwater system, as well as its functioning under future climate change. The strong negative impact of prolonged precipitation shortage on river flow during the drought of 19821994 , characterized by very low probability of occurrence, was registered in all regions of Bulgaria (Gerassimov et al., 2001). The drought influenced groundwater as well (Orehova \& Bojilova, 2001a, 2001b). Therefore groundwater showed its vulnerability to drought. This contribution aims to estimate the resistance of selected karstic aquifers in Bulgaria to drought.

\section{Methodology}

The Drought Resistance Indicator for Karstic Aquifers DRIKA ("l'index de résistance à la sécheresse des aquifères karstiques - IRSAK") was proposed by Collin et al. (1994). The indicator that defines the relative resistance of karstic aquifer systems to drought is determined by the equation

$$
D R I K A=\frac{Q_{\text {min }}}{Q_{\text {min }}}
$$


where $Q_{\mathrm{ax}}$ is the absolute minimal registered discharge of the spring, $\bar{Q}_{\mathrm{ma}}$ the average value of minimal discharges for the given period.

The karstic aquifers are divided into four classes of increasing drought resistance:

$\begin{array}{ll}D R I K A \leq 0,3 & \text { - weak; } \\ 0,3<D R I K A \leq 0,45 & \text { - moderate; } \\ 0,45<D R I K A \leq 0,6 & \text { - good; } \\ D R I K A>0,6 & \text { - high. }\end{array}$

\section{Selection of appropriate stations and general data}

Bulgaria is rich in karstic springs. They drain elevated massifs of karstified marbles, limestones and dolomites (Antonov \& Danchev, 1980; Boyadjiev, 1964). Important karstic massifs are built from Proterozoic marbles.

Sketch map of Bulgaria with the location of the studied springs is presented on Fig. 1. For the aim of this study, perennial karstic springs with long observational period were chosen. Stations showing significant impact of human activity on groundwater were eliminated. Time series of minimal spring discharges for the period 1960 - 2002 were processed. All data originate from National Hydrogeological Network located in the National Institute of Meteorology and Hydrology. The general characteristic of the selected springs is given in Table 1 with indication of their appertainance to the respective territorial unit:

- Danube zone - drainage basin of all Bulgarian tributaries to the river Danube (45\% of the territory of Bulgaria);

- Black sea zone - drainage basin of all Bulgarian rivers with direct discharge to the Black sea $(13,8 \%)$;

- Aegean zone - drainage basin of all South Bulgarian rivers with direct discharge to the Aegean Sea in the territory of Greece and/or Turkey $-41,2 \%$ of the territory of the country.

For some stations (NN 396, 48, 39a) water level recorder is available, for other stations (NN 59, 59a) water level is measured every day by observers. Measurement of spring discharge (using a current meter) is 12 times annually as usual. Using rating curve the daily data for spring discharge were obtained. For the three chosen stations from the Upper Strouma basin (NN 40, 86, 461) and some springs from Danube zone (NN 394), measurements are made once-twice in a month without daily observations on water level. The springs from the Upper Strouma basin, however, show stable discharge during the year.

Seasonal variability of the groundwater regime is discussed by Antonov \& Danchev (1980) and Orehova (2002). As a rule, maximal discharges occur in spring due to snowmelt. For springs in the Danube zone, the most usual case is maximal flows in early spring and minimal ones in October. Minimal springflows are observed in AugustSeptember (48), September-October (39a), February-March (59a), and March-April (59). The three last springs drain Proterozoic marbles from mountain regions (see Table 1). The delay in the extreme for springs 59 and 59a is due to the situation of their watersheds in the high mountain Pirin. The drainage basin of the both springs is located in protected 


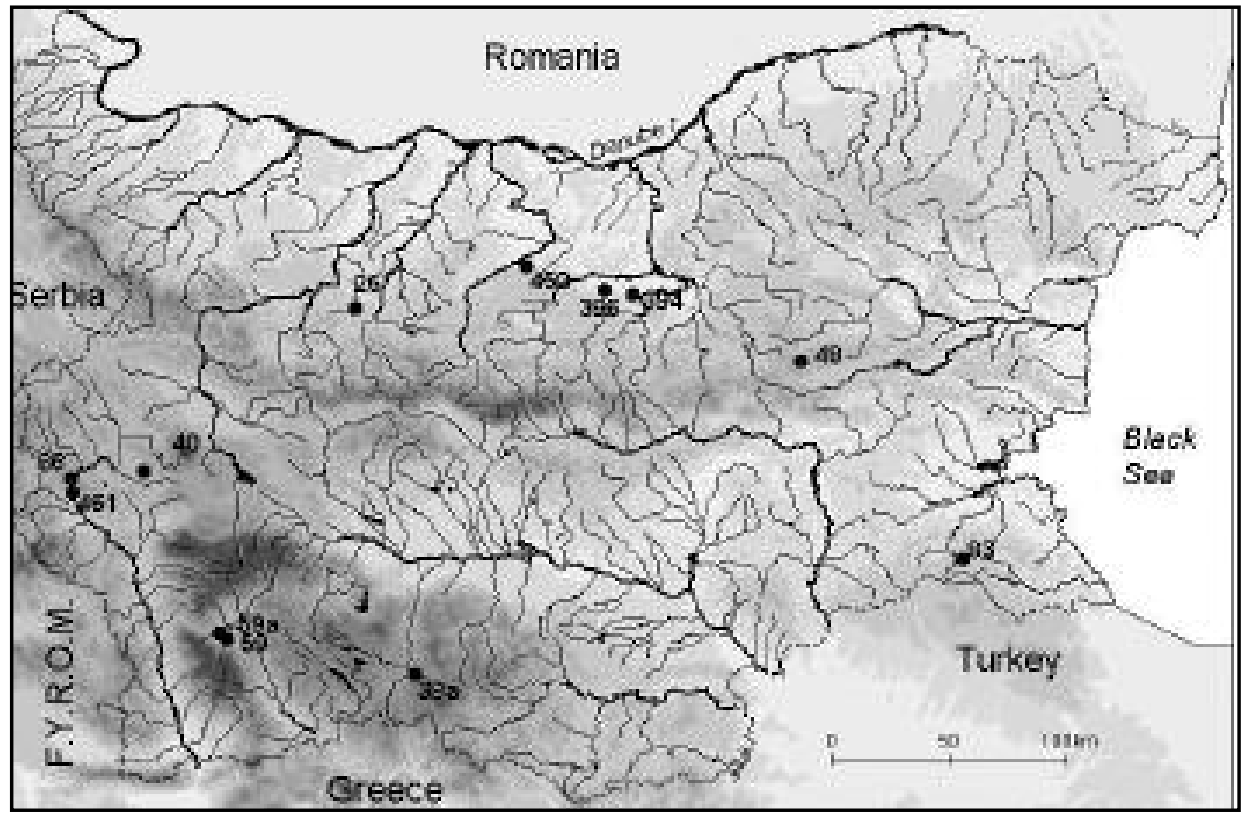

Fig. 1 - Sketch map of Bulgaria with the location of the studied springs

area of Pirin mountain. Pirin National Park is included in the list of UNESCO as a part of World natural heritage. At the spring N 59 the maximum and minimum discharges occur one month later than for the spring N 59a. Most of springs have well defined seasonal cycle. Only springs from the Upper Strouma basin (NN 40, 86 and 461) and spring N 59 show weak seasonal variation throughout the year.

Karstic aquifers in Bulgaria were affected by the drought during 1982-94 (Orehova \&

Fig.2 - Time series of minimal discharge for spring N 59a

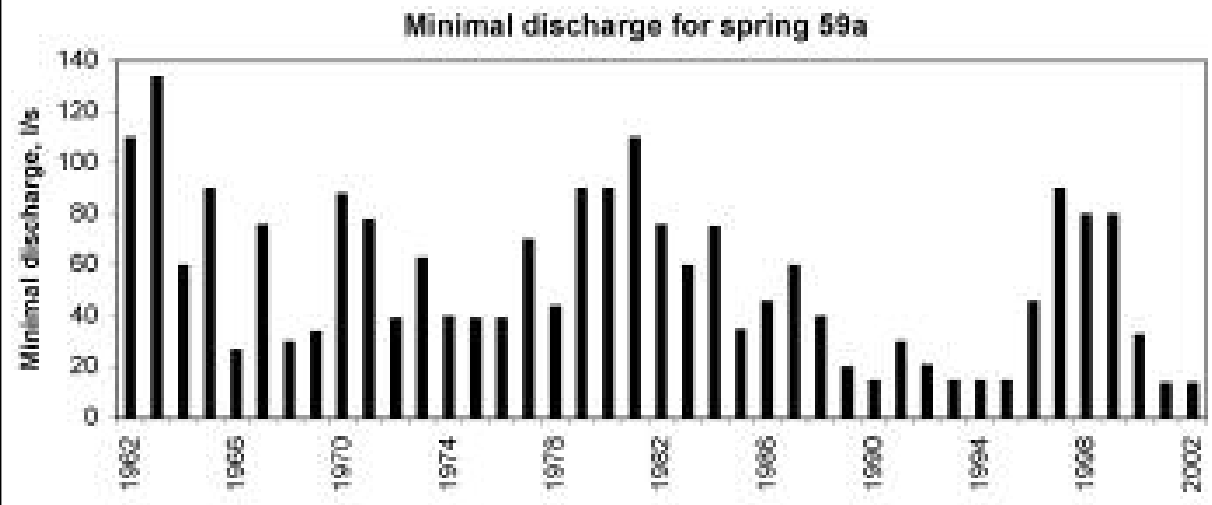


Table 1. General characteristics of the karstic springs

\begin{tabular}{cccccc}
\hline Station N. & Station name & Village & Situation & Geol. Index & Lithological composition \\
\hline 394 & Danube zone & & & & \\
25 & & Beljakovetz & Fore-Balkan & $\mathrm{K}_{1}$ & limestone \\
450 & Glava Panega & Zlatna Panega & Fore-Balkan & $\mathrm{K}_{1}$ & limestone \\
396 & Marata & Krushuna & Fore-Balkan & $\mathrm{K}_{1}$ & limestone \\
\hline \multicolumn{7}{c}{} & Musina & Fore-Balkan & $\mathrm{K}_{1}$ & limestone \\
\hline 48 & Black Sea zone & & & & limestone \\
83 & Kotelski & Kotel & Stara Planina & $\mathrm{K}_{2}$ & limest., marbles \\
\hline \multicolumn{7}{c}{} & Bash.kajnat. & Trakijtzi & Strandja & $\mathrm{T}_{2}+\mathrm{J}_{3}$ & limest., dolomites \\
86 & Aegean Sea zone & & & $\mathrm{T}$ & limest., dolomites \\
461 & & Drugan & Radomir valley & $\mathrm{T}$ & limest., dolomites \\
59 & & P.Skakavitza & Zemen mountain & $\mathrm{T}$ & marbles \\
$59 \mathrm{a}$ & Shegava & Razhdavitza & Konyavo mount. & $\mathrm{Pt}$ & marbles \\
$39 \mathrm{a}$ & Jazo & Razlog & Pirin mountain & $\mathrm{Pt}$ & marbles \\
\hline
\end{tabular}

Table 2. Values of the minimal discharge (I/s) and the indicators for different springs and periods

\begin{tabular}{|c|c|c|c|c|c|c|c|c|c|}
\hline \multirow{2}{*}{$\mathbf{N}$} & \multicolumn{3}{|c|}{$Q_{\text {aix }}$} & \multicolumn{3}{|c|}{$\bar{Q}_{\max }$} & \multicolumn{3}{|c|}{$D R I K A$} \\
\hline & 1960-1981 & 1982-2002 & $1960-2002$ & $1960-1981$ & 1982-2002 & $1960-2002$ & $1960-1981$ & $1982-2002$ & $1960-2002$ \\
\hline & & & & \multicolumn{3}{|c|}{ Danube zone } & & & \\
\hline 394 & 3.3 & 2.3 & 2.3 & 27.7 & 25.1 & 26.5 & 0.120 & 0.092 & 0.087 \\
\hline 25 & 580 & 780 & 580 & 1582 & 1293 & 1438 & 0.367 & 0.603 & 0.403 \\
\hline 450 & 8 & 3 & 3 & 48.7 & 22.5 & 35.9 & 0.164 & 0.133 & 0.084 \\
\hline 396 & 42 & 25 & 25 & 98.5 & 86.7 & 92.8 & 0.426 & 0.288 & 0.269 \\
\hline & & & & \multicolumn{3}{|c|}{ Black Sea zone } & & & \\
\hline 48 & 40 & 52 & 40 & 98.3 & 83.5 & 91.1 & 0.407 & 0.623 & 0.439 \\
\hline 83 & 20 & 30 & 20 & 39.8 & 47.1 & 43.3 & 0.502 & 0.637 & 0.462 \\
\hline & & & & \multicolumn{3}{|c|}{ Aegean Sea zone } & & & \\
\hline 40 & 92 & 43 & 43 & 137.6 & 90.8 & 112.9 & 0.669 & 0.474 & 0.381 \\
\hline 86 & 33 & 19 & 19 & 81.1 & 52.5 & 67.5 & 0.407 & 0.362 & 0.282 \\
\hline 461 & 25 & 11 & 11 & 44.3 & 31.5 & 37.8 & 0.564 & 0.349 & 0.291 \\
\hline 59 & 560 & 415 & 415 & 867.5 & 571.0 & 722.7 & 0.646 & 0.727 & 0.574 \\
\hline $59 a$ & 27 & 14 & 14 & 67.6 & 41.9 & 54.4 & 0.400 & 0.334 & 0.257 \\
\hline $59+59 a$ & 599 & 423 & 423 & 924.8 & 612.6 & 764.9 & 0.648 & 0.691 & 0.553 \\
\hline $39 a$ & 297 & 132 & 132 & 418.1 & 297.7 & 356.38 & 0.710 & 0.433 & 0.371 \\
\hline
\end{tabular}


Bojilova, 2001a, 2001b; Andreeva \& Orehova, 2001) and showed reduction in spring discharge (20-30\% on average). Therefore they demonstrate evident vulnerability to drought. The degree of such vulnerability is discussed in the next section.

\section{Results and discussion}

For the aim of this study, time series of minimal discharge for selected springs were processed (Fig.2). Data from the National Hydrogeological Network for the 1960-2002 period were used. Vulnerability assessment of selected karstic aquifers was made for the entire period, as well as for the two sub-periods, using Equation (1). All classes of drought resistance were received (see Table 2).

The results demonstrated that most of the chosen karstic aquifers in the Danube zone of Bulgaria are weakly resistant. Only the greatest spring (N 25) has moderate to good resistance. It has however specific formation - waters from neighbour watershed are transferred (Antonov \& Danchev, 1980). All massifs are built from karstified limestones and are well drained. In this zone there are many springs getting dry during drought periods. For the aim of this study, however, only perennial spring were chosen.

Karstic aquifers in the Black Sea zone have a good to high resistance - they are built from marbles and limestones of $\mathrm{T}_{2}+\mathrm{J}_{3}(\mathrm{~N} 83)$ and limestones of $\mathrm{K}_{2}(\mathrm{~N} 48)$.

Karstic aquifers in the Strouma river basin (NN 40, 86, 461) are of moderate to good resistance. The aquifers consist of fissured and karstified limestones and dolomites. Their resistance is better than that for aquifers in the Danube zone. This can be attributed to the structure of karstic massifs with high dolomite component: the predominance of small pores or thin fissures in the pore space providing large capacity of the rock mass. Such rocks are less conductive and with better storage capacity compared to pure limestone due to their higher (but very fine) porosity (Collin et al., 1994).

Springs NN 59, 39a from Pirin and Rhodopes regions are of moderate to high resistance. They drain thick massifs of Proterozoic marbles. The comparative analysis of variations in water temperature and discharge for springs 59a and 59 (from Pirin mountain) had lead

Fig. 3 - Graphing the index DRIKA versus average value of minimal discharges

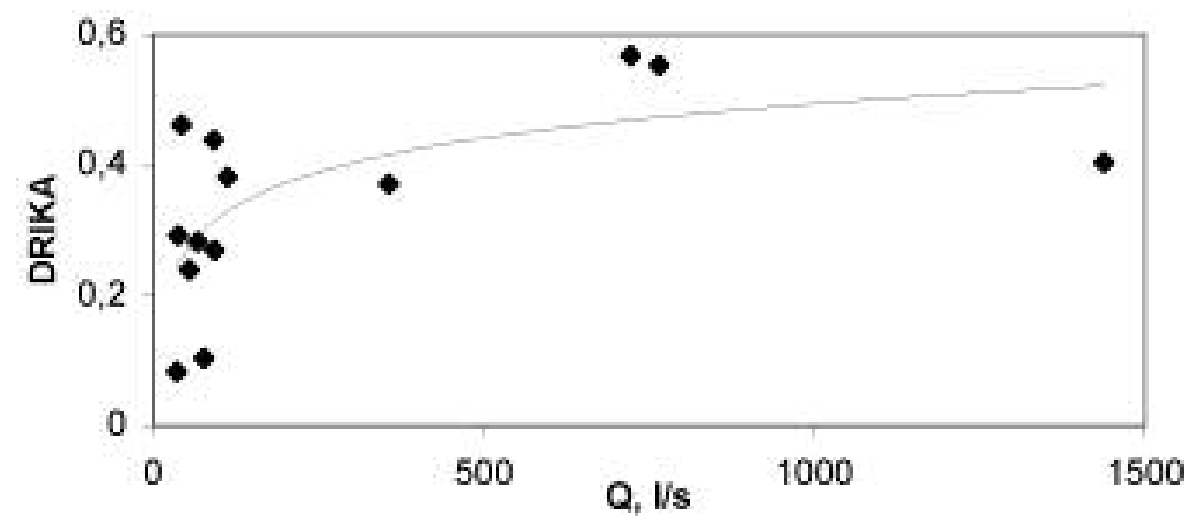


the author to the conclusion that the first one drains upper part of marbles, and the second - deeper part of them (Orehova, 2001). This is the cause for weak resistance to drought for the spring Kjoshka, and its better-defined seasonal variation compared to the spring Jazo.

Probably, karstic aquifers in the Danube zone are more conductive and with less storage capacity compared to the aquifers in Pirin and Rhodopes regions.

We can notice, that for low average values of minimal discharge (approximately below $100 \mathrm{l} / \mathrm{s}$ ), the range of the DRIKA values is rather wide, and for higher values (above 200 1/s) the index is about 0.4 and more (Fig. 3). Evidently, the "resistance to drought" largely depends on the size of the catchment area of the spring.

The index should reflect intrinsic characteristics of the aquifers, but the value of the indicator depends on the observational period as well. Probably, the recharge conditions of some karstic aquifers feeding springs changed during the driest years, when extremely low values of minimal discharge were registered. This might be related to interrupting of additional recharge from surface waters or changing size of the underground catchment area. Good knowledge of the hydrogeological background is of primary importance for estimates of such changes. Obviously, detailed study is necessary in this direction taking into account complicated natural conditions and intensive human impact in many regions.

\section{Conclusions}

The relative resistance of selected karstic aquifers in Bulgaria to a prolonged decrease of recharge was estimated. The drought resistance indicator has been calculated based on the method proposed in report of BRGM (Collin et al, 1994). For the aim of this study, time series of minimal discharges for karstic springs from National Hydrogeological Network were processed.

The degree of the resistance to drought depends on geological and structural peculiarities of the karstic massif, from the catchment area, lithological composition etc. Most of the chosen karstic aquifers in the Danube zone of Bulgaria are weakly resistant. Only the greatest spring ( $\mathrm{N} 25$ ) has moderate to good resistance due to the water transfer from neighbour watershed. All massifs are built from karstified limestone and are well drained. Karstic aquifers in the Black sea zone have a good to high resistance - they are built from marbles and limestone of $\mathrm{T}_{2}+\mathrm{J}_{3}$ and limestone of $\mathrm{K}_{2}$. Karstic aquifers in the Strouma river basin are of moderate to good resistance. They show little seasonal variation throughout the year. Karstic aquifers in Pirin and Rhodopes regions show moderate to high resistance. They drain thick massifs of Proterozoic marbles.

Evidently, the karstic aquifers in the Danube zone are more conductive and with less storage capacity compared to the aquifers in other regions, and therefore they are more vulnerable to drought. The better resistance of springs in the Strouma river basin related with massifs built from limestones and dolomites is due to higher porosity and better storage capacity, as well as worse conductivity.

The value of the indicator depends on the observational period as well that might be related to environmental changes. The results show that most of studied aquifers in Bulgaria have moderate and weak resistance to the drought. They are vulnerable to droughts and need good management for effective use of groundwater resources. 


\section{References}

Andreeva T. \& Orehova T. 2001 - Climate variability and its influence on groundwater in Central Bulgaria during the last decades. Comptes Rendus de l'Académie Bulgare des Sciences 54(11): 39-44.

Antonov H. \& Danchev D. 1980 - Groundwater in the Republic Bulgaria, "Technika", Sofia (in Bulgarian).

Boyadjiev N. 1964 - The karst basins in Bulgaria and their ground waters. Bulletin of the Institute of Hydrology and Meteorology 2: 45-96 (in Bulgarian).

Collin J.-J., Gennai A., Margat J., Landreau A. 1994. Cartographie de la résistance à la sécheresse des systèmes aquifères à nappe libre. Rapport inédit BRGM, Orléans, $94 \mathrm{p}$.

Gerassimov S., Guenev M., Bojilova E., Orehova T. 2001. Water resources in Bulgaria during the drought period - quantitative investigations. 29th IAHR Congress Proceedings. Theme A "Development, Planning and Management of Surface and Ground Water Resources". Tsinghua University Press, Beijing, China: 70-77.

Orehova T. 2001 - Analysis of water temperature variability for some Bulgarian springs. 3rd International Conference "Future Groundwater Resources at Risk", Lisbon, Portugal, 25-27 June.

Orehova T. 2002 - Seasonal variability of the groundwater regime for several aquifers in Bulgaria. Advances in Hydro-Science and -Engineering. Vol. V. Proceedings of the 5-th International Conference on Hydro-Science and -Engineering, Warsaw University of Technology, Faculty of Environmental Engineering, Warsaw, Poland, September 18-20.

Orehova T., Bojilova E. 2001a - Some investigations concerning groundwater regime in the Mediterranean and Black Sea zones in Bulgaria. 3rd International Conference "Future Groundwater Resources at Risk", Lisbon, Portugal, 25-27 June.

Orehova T., Bojilova E. 2001b - Impact of the recent drought period on groundwater in Bulgaria. 29th IAHR Congress Proceedings. Theme A "Development, Planning and Management of Surface and Ground Water Resources". Tsinghua University Press, Beijing, China: 1-6. 